\title{
Complications of urinary tract trauma: case reports
}

\author{
Powikłania urazów układu moczowego - opis przypadków
}

Department of Paediatrics, Paediatric Nephrology and Allergology, Military Institute of Medicine, Warsaw, Poland

Correspondence: Anna Bujnowska, Department of Paediatrics, Paediatric Nephrology and Allergology, Military Institute of Medicine, Szaserów 128,04-141 Warsaw, Poland, e-mail: anka.michalewicz@gmail.com

Abstract Trauma is the most common cause of death among children and adolescents. It is estimated that every year trauma accounts for approximately 830,000 children's deaths worldwide. Urinary tract trauma is relatively rare: it accounts for approximately $3 \%$ of all hospitalisations at trauma centres. It usually occurs as a result of high-energy blunt force trauma to the abdomen and pelvis and most commonly coexists with other internal organ injuries. Abdominal trauma causes damage to the upper levels of the urinary tract: the kidneys and ureters. It may be complicated by haemodynamic disturbances, development of urinoma or kidney loss. Pelvic injuries often coexist with damage to the lower level of the urinary tract and lead to intramural complications of the urinary bladder, urethral stenosis, urinary incontinence or erectile dysfunction. In addition, trauma to any level of the urinary tract can result in urinary tract infection, lesser pelvis tissue inflammation, peritonitis or septic shock. Late complications include urolithiasis, vesicoureteral reflux, hydronephrosis and, consequently, renal failure. From the urinary tract perspective, important consequences of spinal injury also include neurogenic bladder and the associated lower urinary tract dysfunction. The article discusses clinical cases of children presenting with early and late complications of urinary tract injury as a result of multiple high-energy trauma.

Keywords: trauma, urinary tract infection, children, kidney trauma, urinary bladder trauma

Streszczenie Urazy są najczęstszą przyczyną zgonów wśród dzieci i młodzieży. Szacuje się, że odpowiadają rocznie za śmierć około 830000 dzieci na świecie. Urazy układu moczowego są stosunkowo rzadkie - stanowią około 3\% przyczyn wszystkich hospitalizacji w centrach urazowych. Powstają zazwyczaj na skutek wysokoenergetycznych, tępych urazów jamy brzusznej oraz miednicy i najczęściej współistnieją z innymi obrażeniami narządów wewnętrznych. Urazy jamy brzusznej powodują uszkodzenie górnych pięter układu moczowego - nerek i moczowodów. Mogą być powikłane zaburzeniami hemodynamicznymi, powstaniem urinomy czy też utratą nerki. Urazy miednicy natomiast często współistnieją z uszkodzeniem dolnego piętra dróg moczowych i prowadzą do powikłań śródściennych pęcherza moczowego, zwężenia światła cewki moczowej, nietrzymania moczu czy zaburzeń erekcji. Ponadto konsekwencjami urazów wszystkich pięter układu moczowego mogą być zakażenie układu moczowego, zapalenie tkanek miednicy mniejszej, otrzewnej lub wstrząs septyczny. Do powikłań późnych zalicza się m.in.: kamicę dróg moczowych, refluks pęcherzowo-moczowodowy, wodonercze, a w jego następstwie niewydolność nerek. Do ważnych z perspektywy nefrologicznej następstw urazu kręgosłupa należą także pęcherz neurogenny oraz wtórna do niego dysfunkcja dolnych dróg moczowych. W artykule przedstawiono przypadki kliniczne dzieci prezentujących wczesne i późne powikłania urazów układu moczowego, powstałe na skutek mnogich urazów wysokoenergetycznych.

Słowa kluczowe: uraz, zakażenie układu moczowego, dzieci, urazy nerek, uraz pęcherza moczowego 


\section{INTRODUCTION}

$\mathrm{T}$ Trauma is the leading cause of death among children and adolescents and one of the most common reasons for hospital and intensive care admissions. According to the current World Health Organization report, globally, 830,000 children die of unintentional trauma every year ${ }^{(1)}$. The predominant type of injuries are traffic accident-related; the next in order are drowning, falls, burns, accidental poisoning, suffocation and choking ${ }^{(2-4)}$. In 2016 in Poland, 621 children died due to trauma, including 295 in traffic accidents. The trauma mortality rate in the age group of $0-19$ years was 8.1 per 100,000 , including:

- $0-4$ years $-3.7 / 100,000$;

- 5-9 years - 2.3/100,000;

- 10-14 years - 4.5/100,000;

- 15-19 years - as many as $21.7 / 100,000^{(5)}$.

The region of the body which is most commonly affected by trauma is the head (35.87\% of all injuries in children). Head injuries are associated with a $3.74 \%$ mortality rate. Upper extremity trauma $(35.05 \%)$ and lower extremity trauma (30.17\%) are slightly less common. However, chest trau$\mathrm{ma}$ is characterised by the highest mortality rate in this age group: $7.28 \%$ (prevalence of 13.93\%) ${ }^{(6)}$ (Figs. 1, 2).

Genitourinary tract trauma in children is relatively rare: it accounts for approximately $3 \%$ of all paediatric hospitalisations at trauma centres. The main cause is blunt force abdominal trauma ${ }^{(7)}$.

The organs of the urinary tract most commonly affected by trauma (over $50 \%$ ) are the kidneys ${ }^{(8)}$. This is due to their anatomical structure; sometimes congenital defects and kidney diseases also play a role ${ }^{(9)}$. According to the American Association for the Surgery of Trauma scale, kidney injury can be divided into 5 grades: grade I - contusion, sub-

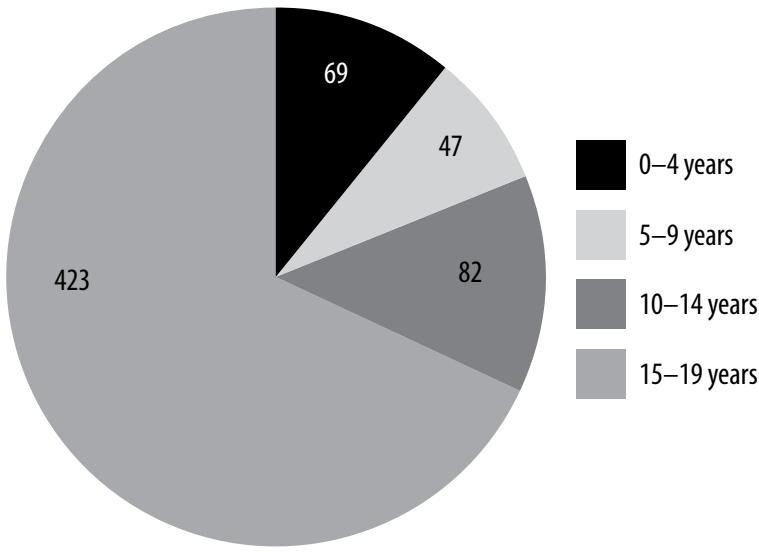

Fig. 1. Number of deaths due to trauma among children (0-19 years of age) in Poland in 2016

capsular haematoma, no parenchymal laceration; grade II nonexpanding perirenal haematoma, parenchymal laceration of $<1 \mathrm{~cm}$; grade III - parenchymal laceration of $>1 \mathrm{~cm}$ without damage to the pelvicalyceal system; grade IV - major laceration extending to the urinary collecting system, haemourinoma, segmental vessel damage, vascular thrombosis; grade $\mathrm{V}$ - shattered kidney, renal vascular pedicle damage. According to the current guidelines developed by the Eastern Association for the Surgery of Trauma (EAST) and Pediatric Trauma Society (PTS), in haemodynamically stable children, conservative management is recommended regardless of kidney trauma severity ${ }^{(10)}$.

Other organs of the genitourinary system are damaged much less frequently.

The most commonly reported ureter injury in childhood is its complete avulsion from the renal pelvis. This type of damage is associated mainly with severe multiple

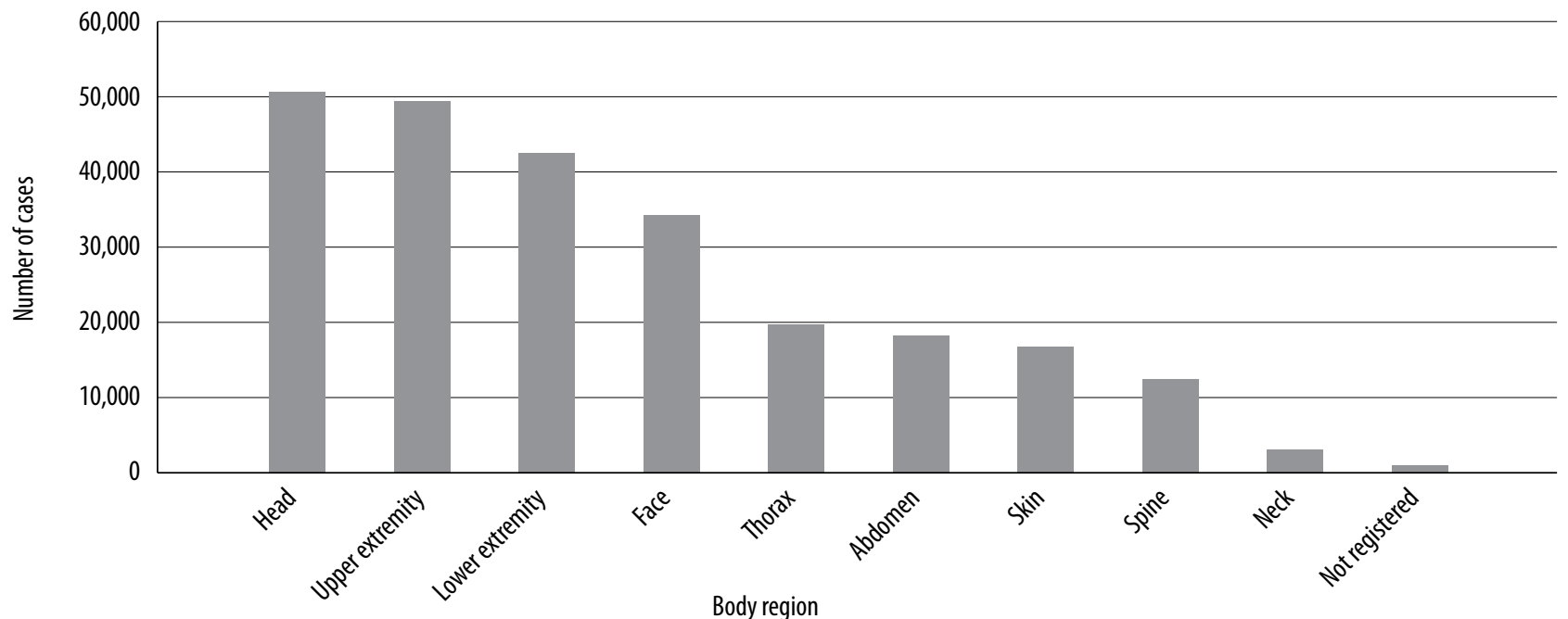

Fig. 2. Number of trauma cases in children by body region as per the Abbreviated Injury Scale (AIS) in the United States of America and Canada in 2016 based on the American College of Surgeons Report ${ }^{(6)}$ 

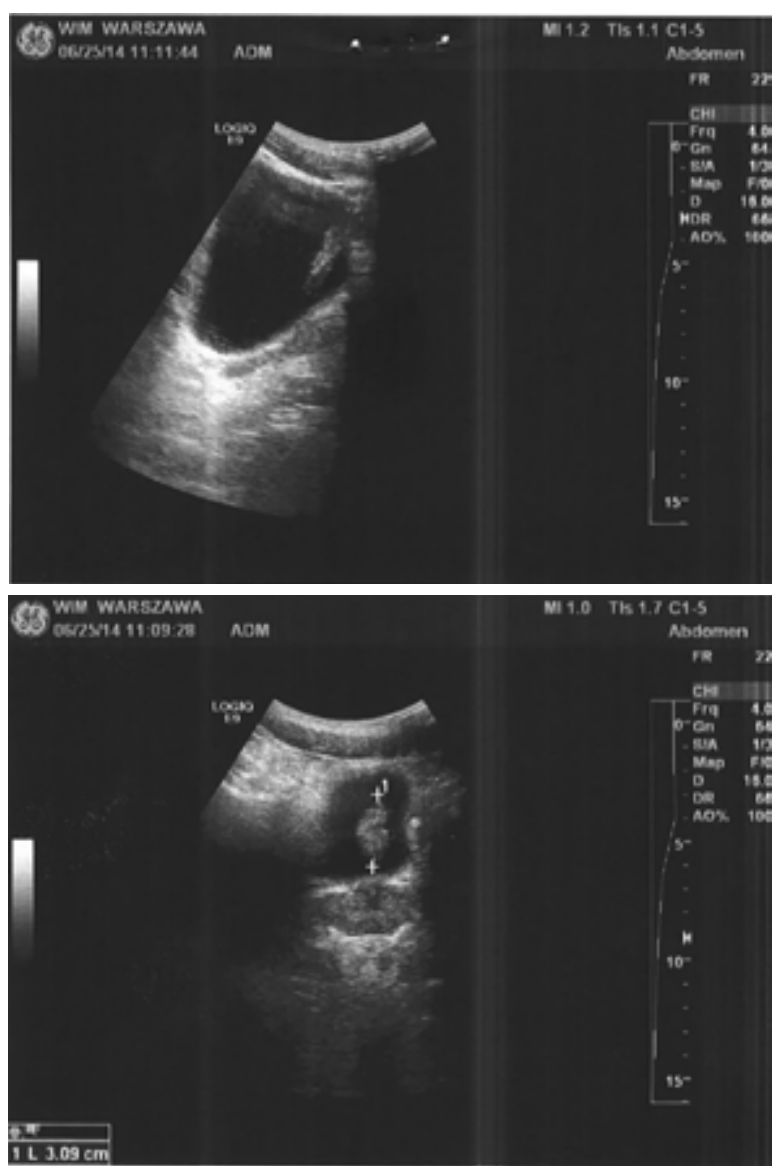

Fig. 3. Ultrasound scan of the sacral bone in a 17-year-old boy following pelvic trauma. The examination revealed a heterogeneous image of the anterior bladder wall with a tissue area of $40 \mathrm{~mm}$ in diameter protruding into the bladder

organ trauma ${ }^{(7)}$. Patient management depends on the degree and level of ureter and kidney damage, and on the child's general condition.

Urinary bladder trauma is often caused by pelvic fracture. The site of damage and location of extravasated urine are the basis of the clinically important division into extra- and intraperitoneal trauma. Bladder wall damage is almost always treated surgically ${ }^{(11)}$.

Urethral damage in boys can occur as a result of penetrating wounds to the penis and urethra, and blunt force perineal injuries. Urethral injury associated with pelvic fracture with pubic bone displacement is less common. Damage to the urethra can also be caused by inadequately performed invasive procedures on the urinary tract or urinary catheterisation. Urethral trauma is much less common in girls than in boys due to anatomical differences (the female urethra is almost completely protected by pelvic bones). The most frequently reported causes of urethral damage in girls are pelvic fractures ${ }^{(7)}$.

Genital injuries, including those of the urethra, can also occur as a result of sexual abuse. The most commonly bruising, abrasions, petechiae, bite marks, ruptured frenulum and tunica albuginea fracture, or penile fracture. In girls with suspected sexual abuse, signs of trauma to the external urethral opening should be searched for and a thorough gynaecological assessment of the labia minora and majora together with the fourchette, and of the hymen and vaginal walls should be performed ${ }^{(12)}$.

Two clinical cases are presented below, which are examples of early and late urinary tract complications associated with multiple high-energy trauma.

\section{CLINICAL CASES}

\section{Case 1}

A 17-year-old boy sustained injuries associated with pelvic trauma as a result of being pinned by a farming tractor. He was initially hospitalised and operated on at a department of trauma medicine. The following injuries were diagnosed: fractured ala of ilium and juxta-articular surfaces of the sacral bone on the right, damaged pubic symphysis syndesmosis, widened joint space of the sacroiliac joint on the left and fractured left inferior pubic ramus. Left sacroiliac joint stabilisation procedure was performed using a cannulated screw. The remaining fractures were treated conservatively. The early postoperative period was uncomplicated (the procedure was performed under antibiotic protection: a first-generation cephalosporin was administered). During hospitalisation at the department of trauma medicine a catheter was placed in the patient's urinary bladder. The patient was discharged on day 3 after orthopaedic surgery with instructions on thrombosis (Fraxiparine $0.4 \mathrm{~mL}$ ) and decubitus prevention.

On the next day, dysuria and fever developed. For this reason, the patient reported to the hospital emergency department. Laboratory tests revealed elevated inflammatory markers [C-reactive protein (CRP) of $12.5 \mathrm{mg} / \mathrm{dL}$, normal range $<0.8$; leukocytosis of $\left.12.6 \times 10^{3} / \mu \mathrm{L}\right]$; on urinalysis, 8-10 white blood cells per high-power field (HPF) and 6-9 red blood cells per HPF were observed. An abdominal ultrasound scan revealed a lesion of approximately $20 \mathrm{~mm}$ at the anterosuperior wall of the urinary bladder, which could be consistent with a haematoma or a tumour (Fig. 3). Otherwise, kidneys, ureters and other abdominal organs appeared normal. Following examination by a urologist, based on ultrasound findings, a Foley catheter was inserted and the bladder was washed with $0.9 \% \mathrm{NaCl}$ (the lavage fluid was clear with no signs of bleeding); subsequently, the catheter was removed.

Due to suspected urinary tract infection, the boy was referred to the Department of Paediatrics, Paediatric Nephrology and Allergology of the Military Institute of Medicine (Wojskowy Instytut Medyczny, WIM), Poland. On admission, the patient was in a relatively good general condition; he remained in a forced, supine position. Physical examination revealed the following significant 
abnormalities: elevated skin temperature, a surgical scar in the lumbar area, tenderness of pelvic bones and conjunctival haemorrhage in the right eye. Based on tests performed at the emergency department, urinary tract infection was diagnosed. The patient was started on cefuroxime and intravenous infusions; anticoagulant and analgesic treatments were continued. Follow-up laboratory tests performed on day 5 of pharmacotherapy revealed the following: erythrocyte sedimentation rate (ESR) of $104 \mathrm{~mm} / \mathrm{h}$, procalcitonin level of $0.09 \mathrm{ng} / \mathrm{mL}$ (normal range $<0.046 \mathrm{ng} / \mathrm{mL}$ ) and CRP of $4.8 \mathrm{mg} / \mathrm{dL}$. Urinalysis showed persistent leukocyturia: 8-10 white blood cells per HPF. Urine culture was sterile, probably due to previous antibiotic therapy.

On another day of hospitalisation the patient was still febrile; he also developed diarrhoea and pain during defecation. On laboratory tests, liver and kidney function markers were normal. A complete blood count showed increased leukocytosis of up to $20.8 \times 10^{3} / \mu \mathrm{L}$ with CRP and procalcitonin values similar to those from the day before. A blood coagulation test revealed elevated D-dimer and fibrinogen levels. There were no signs of infection on a follow-up urinalysis. No rotaor adenovirus antigens were detected on stool analysis. Stool culture did not yield any pathological flora. On ultrasound, apart from a lesion of $40 \mathrm{~mm}$ in diameter in the urinary bladder lumen, abdominal organs appeared normal. Ultrasound examination of the surgery site did not reveal any pathological fluid collections in the structures neighbouring the sacral bone and the surgical fixation. Due to suspected lesser pelvis soft tissue inflammation associated with the trauma, antibiotic therapy was modified: ceftazidime and amikacin were initiated, which lead to fever and diarrhoea resolution and gradual laboratory parameter improvement (CRP $0.3 \mathrm{mg} / \mathrm{dL}$, procalcitonin $0.05 \mathrm{ng} / \mathrm{mL}$ ). During his stay at the department the boy was examined twice by an orthopaedist who did not find any signs of infection at the surgery site. The sutures were removed and the patient received instructions regarding bed rest, decubitus prevention and follow-up at the trauma medicine department on a scheduled date.

During orthopaedic examination approximately 4 weeks later, a gradual return to an upright position was recommended. After 3 days from patient mobilisation, haematuria and urinary bladder pain developed. Urinalysis revealed an increased specific gravity of urine $(1.030 \mathrm{~g} / \mathrm{mL}), 6-10$ white blood cells per HPF and red blood cells loosely covering the high-power field.

Due to the symptoms mentioned above, the boy was readmitted to the Department of Paediatrics, Paediatric Nephrology and Allergology of WIM. Additional tests showed no increase in inflammatory markers, and normal liver and kidney function parameters. Urinalysis did not demonstrate any signs of infection with $0-1$ red blood cells per HPF. On abdominal ultrasound examination, no abnormalities were revealed in the urinary tract.
Computed tomography (CT) of the pelvis revealed a bony adhesion in the left hip joint and an amorphous calcification in the urinary bladder lumen which could be consistent with a calcified haematoma. During orthopaedic examination, based on the CT image of the pelvis and physical examination, the sacroiliac joint was assessed as healed. What was considered the most probable cause of haematuria and the patient's complaints was a fragment of the haematoma observed on imaging studies breaking off the urinary bladder wall. No further complications were noted.

\section{Case 2}

A 17-year-old girl was admitted to the Department of Paediatrics, Paediatric Nephrology and Allergology of WIM due to micturition problems and recurrent urinary tract infections. Four years before admission the girl was involved in a traffic accident and sustained C2-C3 spinal injury. As a result, the girl developed quadriplegia. She required constant urinary bladder catheterisation for approximately a month. Thanks to intensive rehabilitation, motor function was restored; however, from the day of the trauma, the patient suffered from micturition problems and a lack of sensation in the perineal area. After 3 years from the accident, symptom deterioration was observed (periodic urinary incontinence with full micturition, urinary urgency, sporadic nocturnal enuresis). The girl had urinary tract infections three times. For this reason, she received a preventative dose of trimethoprim with sulphamethoxazole. Constipations observed from the girl's birth also deteriorated.

Upon admission to the Department, physical examination did not show any significant abnormalities. Additional tests showed no increase in inflammatory markers, and normal liver and kidney function parameters. Urinalysis and urine culture did not demonstrate any signs of infection. An ultrasound scan showed normal abdominal organs. After micturition there was a sign of residual urine of approximately $5 \mathrm{~mL}$. The patient was then seen by a neurologist. On neurological examination, no significant abnormalities were observed. Magnetic resonance imaging of the lumbar and sacral spine revealed a slight wedgelike deformation of the Th12 and L1 vertebrae. The remaining examined vertebrae were of normal shape and preserved height. The signal obtained from the vertebral bone marrow was unchanged; no focal lesions were visualised. The height of lumbar intervertebral discs was preserved. The presence of a slight posterior herniation of the L5/S1 intervertebral disc was observed, without meningeal sac or nerve root involvement. Apart from that, no intervertebral disc herniation into the vertebral canal was revealed. Lumbar lordosis was preserved. The terminal segment of the spinal cord, conus medullaris and cauda equina roots remained unchanged. The conus medullaris had a normal location at the level of L1. A neurosurgeon did not find any indications for surgical treatment. Subsequently, urodynamic analysis was performed, which 
revealed neurogenic detrusor overactivity with increased bladder sensation, decreased bladder volume, normal bladder wall compliance and high bladder pressure during micturition. The rate of maximum flow in uroflowmetry in relation to pressure during micturition was normal. Urethral flow did not demonstrate the presence of any anatomical or functional infravesical obstruction. Detrusorsphincter coordination was preserved. Voiding cystourethrogram revealed a urinary bladder with uneven wall contours and fine diverticulae, and with a heterogeneous image and urine retention following micturition. No vesicoureteral reflux was visualised. The urethra was normal. Based on the complete clinical presentation and additional tests, neurogenic bladder was diagnosed. The results were consulted with a urologist. Oxybutinin at $3 \times 1 / 2$ tablet was prescribed and regular passing of urine was recommended. A decision was made not to perform cystoscopy and other procedures.

Despite the treatment administered, periodic exacerbation of symptoms was observed in the girl, which was often associated with weather changes.

Due to the fact that the patient turned 18 years of age, further nephrological, urological and neurosurgical care is being provided at healthcare centres for adults.

\section{DISCUSSION}

Genitourinary tract trauma is relatively rare in children, which is due to good protection of the kidneys, ureters and urinary bladder by other abdominal organs and the pelvic skeleton. It usually occurs as a result of high-energy blunt force trauma to the abdomen and most commonly coexists with other internal organ injuries. Isolated urinary tract injuries are rarely observed. Appropriate assessment and management of the sustained injuries by a urological, surgical and paediatric team can reduce the risk of early and late complications such as urinary tract infection, micturition disorders or urolithiasis ${ }^{(13)}$.

In $15 \%$ of cases, pelvic trauma is associated with damage to the lower level of the urinary tract: the urinary bladder and/or urethra ${ }^{(11)}$. Such injuries can be easily overlooked at a trauma medicine department due to the urgent need to take care of life-threatening injuries first. Bone fragments from a fractured pelvis most often cause extraperitoneal rupture of the urinary bladder wall ${ }^{(11)}$. A delayed diagnosis of this type of trauma, particularly if non-sterile urine has entered the peritoneal cavity, can lead to complications such as abscess or lesser pelvis inflammation, peritonitis or septic shock ${ }^{(14)}$. In the boy's case, lesser pelvis tissue inflammation was suspected due to persistent fever and high inflammatory marker values. For this reason, a wide-spectrum antibiotic therapy was used for treatment. The presence of a haematoma in the urinary bladder was probably associated with intramural urinary bladder damage. Such damage often presents with erythrocyturia or haematuria, is self-
Male urethral injuries are divided into anterior trauma (below the external urethral sphincter) and posterior trauma (above the external sphincter); the latter is associated mainly with pelvic trauma and coexists with it in approximately $10 \%$ of cases ${ }^{(13)}$. The most common sign of urethral trauma is the presence of blood in the urethral lumen (37-93\%). In addition, micturition disorders and bruising in the perineal area can develop. In the present case, urethral damage was excluded during urological consultations. Regardless of the type of trauma, one of the first interventions should be catheter insertion $^{(13)}$. This is because immediate attempts at surgical intervention in posterior urethral trauma are associated with a high rate of delayed complications such as erectile dysfunction, urethral stenosis or urinary incontinence ${ }^{(13,16)}$. These can also be associated with late secondary complications such as vesicoureteral reflux and urolithiasis ${ }^{(16)}$. Trauma and the associated prolonged immobilisation of the patient often lead to the complications mentioned above $^{(16)}$. In girls, urethral injuries associated with pelvic trauma are rare, since the female urethra is shorter, more mobile and protected by the pubic bone $\mathrm{e}^{(17)}$. Urethral trauma should be suspected in a patient with swollen labia and vaginal or urethral bleeding. Conservative treatment is usually applied ${ }^{(13,16)}$.

Spinal cord injuries in children are rare (4-8 cases per 1 million). Three main causes of spinal cord injury in children are traffic accidents, falls and violence ${ }^{(18)}$. One of the consequences of spinal cord injury is lower urinary tract dysfunction secondary to neurogenic bladder ${ }^{(19)}$. In turn, functional lower urinary tract disorders can cause many further complications such as urinary tract infections, urolithiasis, vesicoureteral reflux, hydronephrosis and the resultant renal failure ${ }^{(20)}$. The higher risk of stone formation in the urinary tract following spinal cord injury is caused by many factors such as, for example, prolonged immobilisation or reduced mobility, impaired urine outflow, frequent, recurrent urinary tract infections, high intravesical pressure and the associated vesicoureteral reflux. Unfortunately, neurogenic bladder, which is a complication of spinal cord injury, is irreversible in many cases.

Kidney damage due to blunt or penetrating trauma to the abdomen is the most common type of damage to the urinary tract. According to the latest guidelines of $2019^{(10)}$, non-surgical management is recommended for paediatric patients with blunt force kidney trauma of all grades. The only absolute indication for surgical treatment is lack of response to resuscitation, which manifests with persistent haemodynamic instability. The aim of such management is to reduce the rate of kidney loss, blood transfusion and urinoma development. The contemporary methods of blunt kidney trauma treatment include observation, renal angioembolisation, open repair and nephrectomy. Angioembolisation is characterised by a lower complication rate, faster recovery and less frequent kidney loss than open surgery and has become commonly used in patients with bleeding associated with kidney trauma. 
Kidney trauma complications in children also include arterial hypertension. In order to diagnose it early, regular routine blood pressure measurements are recommended ${ }^{(10,13)}$. Trauma is the most common cause of death, disability and social inequality in the paediatric population. The most effective method of reducing their rate seems to be prevention. The European Child Safety Alliance is an organisation of 30 European states, including Poland, which promotes preventative action $^{(21)}$. In Poland, the Child Safety Report Card developed in 2012 is an example of such action ${ }^{(22)}$. Information from such reports may be used to constantly raise society's awareness and undertake concrete preventative measures, the implementation of which plays a very important role.

\section{CONCLUSIONS}

Genitourinary tract trauma in children is rare; it is usually associated with injuries to other internal organs that need to be treated surgically first. However, in every case it is necessary to perform early post-trauma assessment of the urinary tract in order to apply appropriate treatment which can reduce the risk of early and late complications.

\section{Conflict of interest}

The authors do not report any financial or personal affiliations to persons or organisations that could adversely affect the content of or claim to have rights to this publication.

\section{References}

1. World Health Organization: Child injury prevention. Report by the Secretariat. 17 March 2011. Available from: http://apps.who. int/gb/ebwha/pdf_files/WHA64/A64_23-en.pdf.

2. Malinowska-Cieślik M, Balcerzak B, Mokrzycka A et al.: Ocena prewencji urazów i promocji bezpieczeństwa dzieci i nastolatków w Polsce. Zdrowie Publiczne i Zarządzanie 2012; 10: 80-94.

3. Safe Kids Worldwide: Overview of childhood injury morbidity and mortality in the U.S. Fact Sheet. February 2015. Available from: https://www.safekids.org/sites/default/files/documents/ skw_overview_fact_sheet_november_2014.pdf.

4. Centers for Disease Control and Prevention: Web-based Injury Statistics Query and Reporting System. 21 March 2019. Available from: https://www.cdc.gov/injury/wisqars/index.html.
5. Główny Urząd Statystyczny: Rocznik demograficzny 2018. Warszawa, 21 November 2018.

6. American College of Surgeons: Pediatric Annual Report of the National Trauma Data Bank. 2016.

7. Urbanowicz W, Wolnicki M, Sulisławski J et al.: Urazy układu moczowego u dzieci - etiologia, diagnostyka i postępowanie. Rocz Dziec Chir Uraz 2006; 10: 67-75.

8. Urbanowicz W, Wolnicki M, Sulisławski J et al.: Postępowanie i wyniki leczenia w przypadkach urazów nerek u dzieci w latach 1992-2006. Urol Pol 2008; 61: 61-65.

9. Bużański T: Urazy układu moczowego. Post Nauk Med 2014; Suppl 1: 46-50.

10. Hagedorn JC, Fox N, Ellison JS et al.: Pediatric blunt renal trauma practice management guidelines: collaboration between the Eastern Association for the Surgery of Trauma and the Pediatric Trauma Society. J Trauma Acute Care Surg 2019; 86: 916-925.

11. Karim T, Topno M, Sharma $V$ et al.: Bladder injuries frequently missed in polytrauma patients. Open Access J Urol 2010; 2: 63-65.

12. Krajewski W, Wojciechowska J, Krefft $M$ et al.: Urogenital tract disorders in children suspected of being sexually abused. Cent European J Urol 2016; 69: 112-117.

13. Morey AF, Brandes S, Dugi DD $3^{\text {rd }}$ et al.: Urotrauma: AUA guideline. J Urol 2014; 192: 327-335.

14. Delaney KM, Reddy SH, Dayama A et al.: Risk factors associated with bladder and urethral injuries in female children with pelvic fractures: an analysis of the National Trauma Data Bank. J Trauma Acute Care Surg 2016; 80: 472-476.

15. Kong JP, Bultitude MF, Royce $P$ et al.: Lower urinary tract injuries following blunt trauma: a review of contemporary management. Rev Urol 2011; 13: 119-130.

16. Onen A, Subasi M, Arslan $\mathrm{H}$ et al.: Long-term urologic, orthopedic, and psychological outcome of posterior urethral rupture in children. Urology 2005; 66: 174-179.

17. Hagedorn JC, Voelzke BB: Pelvic-fracture urethral injury in children. Arab J Urol 2015; 13: 37-42.

18. Eswara JR, Castellan M, González R et al.: The urological management of children with spinal cord injury. World J Urol 2018; 36: 1593-1601.

19. Zhang Z, Liao L: Risk factors predicting upper urinary tract deterioration in patients with spinal cord injury: a prospective study. Spinal Cord 2014; 52: 468-471.

20. Guzelkucuk U, Demir Y, Kesikburun $S$ et al.: Ultrasound findings of the urinary tract in patients with spinal cord injury: a study of 1005 cases. Spinal Cord 2015; 53: 139-144.

21. European Child Safety Alliance. Available from: https://www. childsafetyeurope.org/index.html.

22. MacKay MVJ, Malinowska-Cieślik M, Mokrzycka A et al.: Child Safety Report Card 2012: Poland. European Child Safety Alliance, Birmingham 2012. Available from: http://www.childsafetyeurope.org/reportcards/info/poland-report-card.pdf. 